\title{
SISTEM DEMOKRASI DAN KEKHILAFAAN DALAM SYARIAT ISLAM
}

\author{
Ogi Habibi, SQ., MH. \\ Universitas Islam Negeri (UIN) Alauddin Makassar \\ muhammadoghy@gmail.com
}

\section{Abstrak}

Materi tentang khilafah merupakan pembahasn yang panas ketika diperbincangkan khususnya di Indonesia. Sebagian menolak dengan sangat keras dan sebagian lain menerima dengan senang hati. Sebab penolakan berbeda-beda; ada yang karena memang beragama dan kepercayaan yang berbeda, ada yang kerena merasa bahwa dengan berdirnya khilafah maka akan ada upeti dan dan pajak yang tinggi selayaknya zaman-zaman kerajaan jahiliyah terdahulu, ada pula yang merasa ketakutan karena hukum syariat Islam yang akan ditegakkan atau tidak sesuai dengan paham demokrasi di Indonesia dan berbagai macam alasan-alasan lain yang terkadang terasa menggelikan saat mendengarkannya. Sedang bagi yang pro terhadap khilafah, maka dengan tenangnya beralasan bahwa memang sudah seharusnya berdiri karena negara Indonesia berpenduduk mayoritas Islam bahkan masuk kategori negara dengan penduduk dan masyarakat Islam terbanyak di seluruh dunia.

Keyword: Sistem Demokrasi, Kekhilafaan, Syariat Islam 


\section{A. Latar Belakang}

Islam merupakan agama universal yang mencakup semua aspek kehidupan manusia, mempunyai hubungan yang terpadu dan terintegrasi dengan politik, sosial, ekonomi, dan budaya. Islam mengatur kehidupan manusia di bumi, tidak hanya memberikan padoman dalam aspek akidah, ibadah, dan akhlak, tetapi juga dalam bidang kemasyarakatan. Ajaranajaran kemasyarakatan tidak mungkin terlaksana tampa dukungan kekuasaan negara. Mendirikan suatu negara atau pemerintahan untuk mengelola urusan rakyat merupakan kewajiban negara yang paling agung, karena agama tidak mungkin tegak tanpa negara dan pemerintahan. Ukuran tegaknya suatu nilai-nilai agama seperi keamanan, keadilan, keteraturan hanya mungkin dilakukan melalui negara atau pemerintahan. Menurut Ibn Taimiyah, bahwa umat manusia tidak akan mungkin mencukupi segala kenutuhan tanpa kerjasama dan saling membantu dalam kehidupan kelompok dan setiap kehidupan kelompok atau bermasyarakat memerlukan seorang kepala atau pemimpin. ${ }^{1}$

Seorang pemimpin harus memegang janji, jujur, amanah dan bertanggung jawab untuk menjalangkan kekuasaannya berdasarkan kepentingan umum, inilah intisari ajaran Islam. kepemimipinan bukan suatu yang perlu dibanggakan tetapi merupakan bentuk pengabdian dan pertanggungjawaban terhadap prinsip-prinsip keimanan. Seorang yang di angkat menjadi pemimpin harus memegang komitmen untuk menunaikan kewajiban kepemimpinannya dalam rangka mewujudkan kemaslahatan bersama, karena pemimpin adalah

${ }^{1}$ Munawir Sjadzali, Islam dan Tata Negara; Ajaran Sejarah dan Pemikiran (Cet. V; Jakarta: UI Press, 1993), Hlm. 89. 
amanah yang akan dipertanggungjawabkan kepada rakyat yang dipimpin dan kepadah Allah. ${ }^{2}$

Dalam Islam, menentukan pemimpin tidak dijelaskan secara jelas atau tidak ditetapkan, seperti persoalan pertama yang dihadapi kaum muslimin setelah Rasulullah wafat. Rasulullah tidak menentukan siapa yang akan menggantikan dan bagaimana mekanisme pergantian itu dilakukan. Dalam sejarah Islam dikenal sebagai mekanisme penetapan kepala negara, dan tentu saja dengan berbagai kriteria yang sesuai. Dalam kasus al-Khulafa al-Rasyidin, Abu Bakar ditetapkan berdasarkan pemilihan suatu musyawarah terbuka, Umar bin Khattab ditetapkan berdasarkan penunjukan kepala negara pendahulunya, Usman bin Affan ditetapkan berdasarkan pemilihan dalam suatu dewan formatur dan Ali bin Abi Talib ditetapkan berdasarkan pemilihan melalui musyawarah dalam pertemuan terbuka. Fase ini disebut fase pembentukan khilafah. ${ }^{3}$

Khilafah adalah lembaga pemerintahan dalam Islam, ${ }^{4}$ sedangkan dalam masyarakat modern dikenal dengan demokrasi yaitu suatu atauran kelembagaan dalam rangka mengambil suatu keputusan politik dimana masing-masing orang memiliki kekuatan untuk memutuskan dan berjuang secara kompetitif untuk memperoleh dukungan atau suara rakyat. $^{5}$

2Syarifuddin Jurdi, Pemikiran Polotik Islam Indonesia: Pertautan Negara, Khilafah, Masyarakat Madani dan Demokrasi (Yogyakarta: Pustaka Belajar, 2008), Hlm. 60.

${ }^{3}$ Djazuli, Fikh Siyasah: Implemetasi kemaslahatan Umat dalam Rambu-Rambu Syariah (Cet. III; Jakarta: Prenada Media Group, 2003), Hlm. 17.

4 Abdul Aziz Dahlan, Ensiklopedia Hukum Islam (Cet. I; Jakarta: Ichtiar Baru Van Hoeve, 1996), Hlm. 918.

${ }^{5}$ Muhammad Mahmud MD, Demokrasi dan Konstitusi di Indonesia (Cet. II; Jakarta: PT Rineka Cipta, 2003), Hlm. 19.

Sangaji Jurnal Pemikiran Syariah dan Hukum 
Berdasarkan hal tersebut, peneliti tertarik ingin mengkaji lebih dalam tentang bagaimana yang dimaksud dengan sistem demokrasi dan sistem kekhilafaan. Bertolak dari latar belakang masalah, untuk mempertajam dan mensistematiskan pembahasan ini, maka penulis mengangkat pokok permasalahan yaitu "Bagaimana sistem demokrasi dan kekhilafaan dalam syariat Islam". Dan untuk menjelaskan pokok permasalahan tersebut, maka diperinci lebih lanjut dalam beberapa sub masalah, yakni: bagaimana yang dimaksud dengan sistem demokrasi, serta bagaimana dan seperti apa sebenarnya yang dimaksud dengan sistem kekhilafaan?

\section{B. Sistem Demokrasi}

\section{Pengertian Demokrasi}

Secara harfiah kata demokrasi berasal dari bahasa Yunani "demos" (masyarakat) dan "kratia" (aturan atau kekuasaan) dan demokrasi berarti kekuasaan di tangan rakyat atau pemerintahan oleh dan untuk rakyat mayoritas. Dengan demikian demokrsi dapat berarti sistem pemerintahan yang berlawanan dengan sistem pemerintahan yang hanya di tangan seseorang atau pemerintahan yang dipimpin oleh hanya beberapa orang saja. ${ }^{6}$

Sedangkan pengertian demokrasi secara teminologi adalah sebagai berikut:

a) Menurut Abraham Lincoln, demokrasi adalah suatu pemerintahan dari rakyat, oleh rakyat dan untuk rakyat.

b) Menurut Josept A.Schupeter, demokrasi adalah suatu perencanaan institusional untuk mencapai keputusn politik dimana individu-individu memperoleh

6 Fuad Fachruddin, Agama dan Pendidikan Demikrasi, Pengalaman Muhammadiyah dan Nahdlatul Ulama (Cet. I; Jakarta: Pustaka Alvabet, 2006), Hlm.25-26. 
kekuasaan untuk memutuskan dengan cara perjuangan komperatif atas suara rakyat. ${ }^{7}$

c) Menurut Ichlasul Amal, demokrasi adalah suatu sistem yang paling memberikan kesemoatan pilihan kepada rakyat, untuk berbeda pandangan, menyatakan perndapat secara bebas, tidak ada ketakutan.

Dari beberapa definisi yang telah diungkapkan, maka dapat disimpulakan bahwa demokrasi mengandung makna suatu sistem pemerintahan atau aturan dalam masyarakat yang mengikut sertakan seluruh anggota masyarakat baik secara langsung maupun malalui perwakilan unutk mengambil keputusan yang menyangkut soal-soal kenegaraan dan kepentingan bersama, dengan berlandaskan kepada nilai-nilai kebersamaan, keadilan, dan kebebasan.

Demokrasi secara sempit dapat didefinisikan sebagai suatu jenis sistem pemerintahan. Demokrasi adalah suatu aturan kelembagaan dalam rangka mengambil suatu keputusan politik di mana masing-masing orang memiliki kekuatan untuk memutuskan dan berjuang secara kompratif untuk memperoleh dukungan atau suara rakyat. Demokrasi juga bisa diartikan sebagai alat untuk melindungi masyarakat yang dipimpin dari dari penyalahgunaan kekuasaan oleh yang memimpin. Demokrasi adalah suatu sistem politik dengan konsep kedaulatan di tangan rakyat, penguasa mempertanggungjawabkan secara berkala terhadap yang dipimpinnya, hak minoritas (termasuk hak untuk menyadi mayoritas), dilindungi,dan persaingan politik antarindividu dan antargagasan sangat terbuka. ${ }^{8}$

7 Masykuri Abdillah, Respons of Indonesia Muslim Intelectuals to the Concept of Democracy (Cet. I. Yogyakarta: Taitara Wacana, 1999), Hlm. 72.

${ }^{8}$ Muhammad Mahmud MD, Demokrasi dan Konstitusi di Indonesia. Hlm. 19.

Sangaji Jurnal Pemikiran Syariah dan Hukum 
Pemerintah yang demokrasi dicirikan dengan pelaksanaan pemilihan umum yang bebas dan terbuka dengan terjamin kerahasiaan pemungutan suara; memakai prinsip satu orang satu suara; adanya pembagian dan pemisahan kekuasaan alam pemerintahan; keadilan dan kedudukan yang sama bagi setiap orang di hadapan hukum; membuka komunikasi antara masyarakat dengan pihak pemerintah; dan menegakkan hak asasi manusia seperti kebebasan berbicara, berekspresi atau kebebasan beragama.

Dalam pengertian luas, demokrasi tidak hanya dipahami sebagai suatu bentuk pemerintahan, dan lebih dari undang-undang dasar, pemilihan umum, dan aturan hukum, demokrasi juga dapat diartikan sebagai cara hidup, adanya keinginan untuk berkompromi, toleransi dan kesediaan mendengar dan menerima pendapat orang lain. Demokrasi juga dapat didefinisikan sebagai penerimaan kontrak sosial yang menuntut perilaku bertanggungjawab, kewarganegaraan yang baik, dan keyakinan/pandangan bahwa tidak ada seorangpun yang memiliki kedudukan lebih tinggi daripada hukum. ${ }^{9}$

Demokrasi terdiri dari dua dimensi: politik formal dan proses partisipatif. Yang dimaksud dengan politik formal adalah pemberian hak suara, pemilihan umum dan partai politik. Merujuk kepada politik formal, demokrasi secara sederhana dilihat sebagai mekanisme pasar, yaitu mentamsilkan pilihan sebagai konsumen dan para politisi sebagai pengusaha. Untuk mendapat dukungan publik (massa), para politisi menggunakan berbagai cara (misalnya kasus politik uang). Demokrasi sebagai proses partisipatif menunjukkan keterlibatan masyarakat dalam menetukan

9 Fuad Fachruddin, Agama dan Pendidikan Demikrasi, Pengalaman Muhammadiyah dan Nahdlatul Ulama. Hlm.26-27. 
program-program dan kebijakan-kebijakan yang dibuat oleh pemerintah. Dilihat dari dimensi partisipatori, demokrasi bertujuan memberdayakan masyarakat untuk mengambil keputusan-keputusan dan kebijakan-kebijakan secara adil. Oleh karena itu, demokrasi idealnya dapat memotivasi dan mendorong semua orang untuk berpartisipasi dalam pengambilan keputusan.

Demokrasi mengandung dua elemen penting: kemerdekaan atau kebebasan, dan kesetaraan. Kebebasan didefinisikan sebagai suatu kemampuan untuk bertindak berdasarkan keinginan seseorang. Kebebasan individu meliputi kebebasan berbicara atau berekspresi, kebebasan beragama, bebas dari bahaya dan rasa takut, bebas berserikat, termasuk kebebasan bagi setiap individu untuk berpartisipasi dalam pembentukan pemerintahan sebagai hak dasar dari manusia. kesetaraan menjadi elemen terpenting kedua yang terkandung dalam demokrasi, dan memiliki berbagai macam bentuk. Setiap manusia yang memiliki latar belakang berbeda seperti ras, agama, atau status ekonomi seharusnya memiliki hak yang sama; yaitu mereka harus diperlukan secara adil di hadapan hukum. Di arena politik, mislanya, setiap warga negara harus memiliki peran yang sama dan langsung dalam pengmabilan keputusan. ${ }^{10}$

\section{Sejarah Demokrasi}

Konsep demokrasi semula lahir dari pemikiran mengenai hubungan negara dan hukum di Yunani Kuno dan dipraktekkan dalam hidup bernegara antara abad ke-4 sebelum Masehi sampai abad ke-6 Masehi. Pada waktu itu dilihat dari pelaksanaannya, demokrasi yang diperaktekkan

10 Fuad Fachruddin, Agama dan Pendidikan Demikrasi, Pengalaman Muhammadiyah dan Nahdlatul Ulama. Hlm. 28.

Sangaji Jurnal Pemikiran Syariah dan Hukum 
bersifat langsung; artinya hak rakyat untuk membuat keputusan-keputusan politik dijalankan secara langgsung oleh seluruh warga negara yang bertindak berdasarkan prosedur mayoritas. Sifat langsung ini dapat dilaksanakan secara efektif karena negara Yunano Kuno berlangsung dalam kondisi sederhana dengan wilayah negara yang hanya terbatas pada sebuah kota dan daerah sekitarnya dan jumlah penduduk yang hanya lebih kurang 300.000 orang dalam satu negara. Lebih dari itu ketentuan-ketentuan demokrasi hanya berlaku untuk warga negara resmi yang merupakan sebagian kecil dari seluruh penduduk. Sebagian besar yang terdiri dari budak berlian, pedagang asing, perempuan dan anak-anak tidak dapat menikmati hak demokrasi. ${ }^{11}$

Gagasan demokrasi Yunani boleh dikatakan lenyap dari muka Dunia Barat ketika bangsa Romawi dikalahkan oleh suku bangsa Eropa Barat dan bangsa Eropa memasuki abad pertengahan (600-1400), masyarakat abad pertengahan ini dicirikan oleh struktur sosial yang feodal; kehidupan sosial dan spiritualnya dikuasai oleh Paus dan pejabatpejabat agama, sedangkan kehidupan politiknya ditandai oleh perebutan kekuasaan di antara para bangsawan. Dengan demikian masyarakat abad pertengahan terbelenggu oleh kekuasaan foedal dan kekuasaan pemimpin-pemimpin agama, sehingga tenggelam dalam apa yang disebut sebagai masa kegelapan. Kendati begitu ada sesuatu yang penting berkenaan dengan demokrasi pada abad pertengahan itu, yakni lahirnya dokumen Magna Charta (Piagam Besar), suatu piagamyang berisikan semacam perjanjian antara beberapa bangasawan dan raja John di Inggris bahwa Raja mengakui dan menjamin

${ }^{11}$ Muhammad Mahmud MD, Demokrasi dan Konstitusi di Indonesia. Hlm. 20-21. 
beberapa hak dan bawahannya sebagai imbalan untuk penyerahan dana bagi keperluan perang dan lain-lain. Lahirnya Piagam ini, kendati tidak berlaku bagi rakyat jelata, dapat dikatakan sebagai lahirnya tonggak baru bagi perkembangan demokrasi, sebab dari piagam tersebut terlihat adanya dua prinsip dasar; pertama, kekuasaan raja harus dibatasi; kedua, hak asasi manusia lebih penting daripada kedaulatan raja. ${ }^{12}$

Munculnya kembali prinsip demokrasi di Eropa Barat sangat didorong oleh terjadinya perubahan sosial dan kultural yang berintikanpendekatan pada pemerdekaan akal dari berbagai pembatasan. Dua kejadian besar yakni "Renaissance" dan "Reformasi" telah menandai perubahan besar tersebut. ${ }^{13}$

Renaissance adalah aliran yang menghidupkan kembali minat pada sastra dan budaya Yunani Kuno, yang berupa gelombang-gelombang kebudayaan dan pemikiran yang dimulai di Italia pada abad keepatbelas dan mencapai puncaknya pada abad kelimabelas dan keenambelas. Masa Renaissance adalah masa di mana orang orang mematahkan semua ikatan yang ada dan menggantikan dengan kebebasan bertindak yang seluas-luasnya sepanjang sesuai dengan yang dipikirkan, karena dasar dari ide ini adalah kebebasan berfikir dan bertindak bagi manusia tampa boleh ada orang lain yang menguasai atau membatasai dengan ikatan-ikatan. Hal ini di samping tentunya mempunyai segi positif yang cemerlang dan gemilang karena telah mengantarkan dunia pada kehidupan yang lebih modern dan mendorong berkembang pesatnya ilmu pengetahuan

12 Mariam Budiardjo, Dasar-dasar Ilmu Politik (Jakarta: PT Gramedia, 1982), Hlm. 54-55.

${ }^{13}$ Muhammad Mahmud MD, Demokrasi dan Konstitusi di Indonesia. Hlm. 22.

Sangaji Jurnal Pemikiran Syariah dan Hukum 
dan teknologi - telah pula memberi sisi buruknya sendiri, sebab dengan adanya pemikiran untuk lepas dari semua ikatan, berkembanglah sifat-sifat buruk dan sosial seperti kebencian, iri hati atau cemburu yang dapat meracuni penghidupan yang mengakibatkan terjadinya perjuangan sengit di setiap lapangan dengan saling bersiasat, membujuk, menipu, atau melakukan apa saja yang diinginkan kendati melalui cara yang tercelah secara moral. $^{14}$

Peristiwa lain, selain renaissance yang mendorong tinbulnya kembali "demokrasi" yang dahulunya tenggelam dalam abad pertengahan adalah terjadinya reformasi, yakni revolusi agama yang terjadi di Eropa Barat pada abad keenam belas yang mulanya menunjukkan sebagai pergerakan perbaikan keadaan dalam gereja Katolik tetapi kemudian berkembang menjadi asas-asas Protestanisme. Reformasi dimulai ketika Martin Luther menempelkan 95 dalil pada pintu gereja Wattenberg (31 Oktober 1517) yang kemudian segera memancing terjadinya serangan terhadap gereja. Luther mempunyai ajaran tentang pengampunan dengan kepercayaan saja, sebagai pengganti upacaraupacara, pekerjaan baik dan perantaraan gereja, serta mendesak supaya membaca kitab suci yang ternyata telah memberikan pertanggungjawaban lebih besar kepada perseorangan untuk keselamatan sendiri. Ajaran yang kemudian disambut di mana-mana itu telah menyulut api pemberontakan secara cepat dan meluas di Jerman dan sekitarnya, sengketa dengan gereja dan kaisar berjalan lama dan getir yang tidak terselesaikan dengan diselenggarakannya muktamar-mukatamar di Speyer (1526, 1529) dan di Augsburg (1530). Berakhirnya reformasi

14 R. Wiranto, Djamaluddin Dt, Singomangkuto dan Djamadi, Ahli-ahli Pikir Besar Tentang Negara dan Hukum (Jakarta: PT Pembangunan, 1980), Hlm. 91. 
ditandai dengan terjadinya perdamainya Westphalia (1648) yang ternyata mampu menciptakan keseimbangan setelah kelelahan akibat perang yang berlangsung selama 30 tahun. ${ }^{15}$

\section{Unsur-Unsur Demokrasi}

Menurut Robert A. Dahl bahwa unsur-unsur demokrasi adalah sebagai berikut:

a) Menyelenggarakan pemilihan yang terbuka dan bebas.

b) Mengembangkan pola kehidupan politik yag kompetitif.

c) Memberi perlindungan terhadap kebebasan masyarakat.

Selain dari apa yang telah diungkapkan oleh A. Dahl juga di ikuti oleh Juan Linz yang mengemukakan unsurunsur demokrasi yang lebih ketat:

a) Memberi kebebasan bagi masyarakat untuk merumuskan preverensi-preverensi pelotik mereka, melalui jalur-jalur perserikatan, informasi dan komunikasi.

b) Memberikan kesempatan bagi warganya untuk bersaing secara teratur, melalui cara damai.

c) Tidak melarang siapapun untuk memperebutkan jabatan-jabatan politik yang ada. ${ }^{16}$

Menurut Franz Magnis-Suseno mengungkapkan bahwa negara baru dapat dikatakan demokrasi apabila ia memenuhi lima ciri-ciri demokrasi:

a) Negara hukum

b) Pemerintah dibawah kontrol nyata masyarakat

c) Ada pemilihan umum berkala bebas

d) Prinsip mayoritas

${ }^{15}$ Muhammad Mahmud MD, Demokrasi dan Konstitusi di Indonesia. Hlm. 24.

${ }^{16}$ Nasir Tamara dan Elza Peldi Taher, Agama dan Dialog Antar Peradaban (Cet. 1; Jakarta: Paramadina, 1996), Hlm. 89.

Sangaji Jurnal Pemikiran Syariah dan Hukum 
e) Adanya jaminan terhadap hak-hak demokrtis dasar. ${ }^{17}$

Berdasarkan unsur-unsur tersebut, maka jelas bahwa demokrasi merupakan konsep yang sangat ideal. Semua unsur-unsur termasuk (kebebasan untuk berpendapat, kebebasan berserikat, pemilihan umum yang bebas dan terbuka dan negara itu berdasarkan hukum) harus secara keseluruhan dipenuhi sebelum sebuah bentuk pemerintahan dikatakan demokraris.

\section{Hubungan Demokrasi dan Islam}

Sistem pemerintahan demokrasi sebagian pakar mengatakan bahwa itu adalah sistem pemerintahan yang tidak sesuai dengan Islam. Hal ini disebabkan karena mereka menganggap bahwa demokrasi berasal dari Barat. Namun bukan berarti prinsip-prinsip demokrasi sesungguhnya bertentangan denhgan Islam bahkan dalam prinsip-prinsip tersebut tidak didapatkan pertentangan.

Adapun prinsip-prinsip demokrasi yang sesuai dengan Islam adalah sebagai berikut:

a) Persaudaraan

Dalam konsep persaudaraan sangat dijunjung tinggi, terlebih lagi dalam agama Islam, persaudaraan tidak hanya terbatas pada persaudaraan sekandung, akan tetapi lebih dari itu termasuk persaudaraan seagama, sesuku, dan sebangsa. Sebagaimana dalam QS. Al-Hujurat: 10.
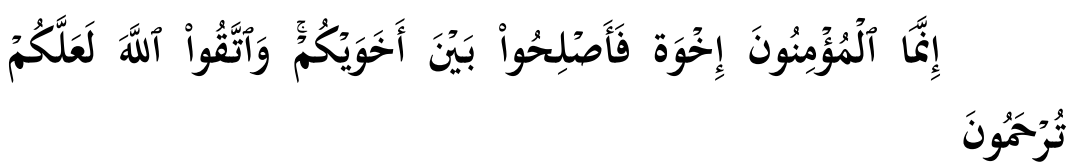

${ }_{17}$ Nasir Tamara dan Elza Peldi Taher, Agama dan Dialog Antar Peradaban, Hlm. 127. 
Terjemahnya:

"Orang-orang beriman itu Sesungguhnya bersaudara. sebab itu damaikanlah (perbaikilah hubungan) antara kedua saudaramu itu dan takutlah terhadap Allah, supaya kamu mendapat rahmat." 18

b) Persamaan

Prinsip persamaan merupakan salah satu prinsip demokrasi karena sesungguhnya manusia itu sama, tidak ada perbedaan antara orang lemah dan orang kuat. Dalam Islam juga tidak ada perbedaan antara manusia yang satu dengan yang lainnya, yang membedakan hanyalah takwanya. Sebagaimana dalam QS. Al-Hujurat: 13.

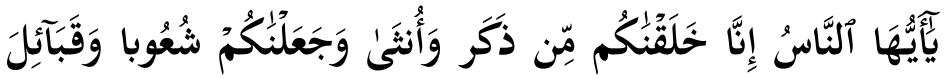

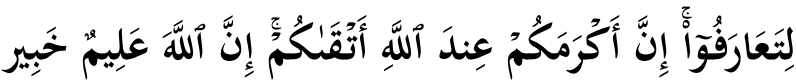

Terjemahnya:

"Hai manusia, Sesungguhnya Kami menciptakan kamu dari seorang laki-laki dan seorang perempuan dan menjadikan kamu berbangsa-bangsa dan bersuku-suku supaya kamu saling kenal-mengenal. Sesungguhnya orang yang paling mulia diantara kamu disisi Allah ialah orang yang paling taqwa diantara kamu. Sesungguhnya Allah Maha mengetahui lagi Maha Mengenal."19

c) Kebebasan

Prinsip kebebasan yang berarti bebas berbuat, asal tidak menggangu orang lain serta tidak melanggar aturan-aturan yang ada. Begitupun dalan Islam setiap

18 Departemen Agama RI, Al-Qur'an dan Terjemahannya, (Jakarta: Da>r As-Sunnah, 2002 M), Hlm. 516.

${ }^{19}$ Departemen Agama RI, Al-Qur'an dan Terjemahannya, Hlm. 517.

Sangaji Jurnal Pemikiran Syariah dan Hukum 
Individu bertanggungjawab atas perbuatannya dan menentukan nasibnya sendiri. Sebagaimana dalam QS. Al-An'am: 164.

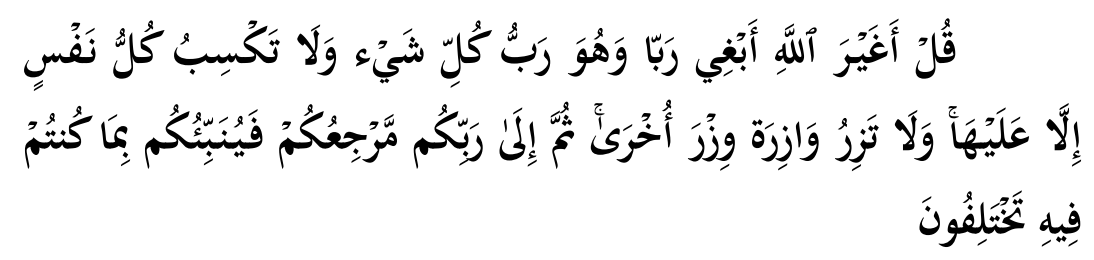

Terjemahnya:

"Katakanlah: "Apakah aku akan mencari Tuhan selain Allah, Padahal Dia adalah Tuhan bagi segala sesuatu. dan tidaklah seorang membuat dosa melainkan kemudharatannya kembali kepada dirinya sendiri; dan seorang yang berdosa tidak akan memikul dosa orang lain. kemudian kepada Tuhanmulah kamu kembali, dan akan diberitakan-Nya kepadamu apa yang kamu perselisihkan." 20

d) Keadilan

Prinsip keadilan dalam konsep demokrasi sangat dibutuhkan oleh karena setiap orang dituntut untuk berlaku adil, baik untuk dirinya maupun kepada orang lain. Terlebih lagi dalam Islam setiap orang yang beriman dituntut untuk menegakkan keadilan, bahkan dilarang untuk meyeleweng kebenaran. Sebagaimana dalam QS. An-Nisa': 58.

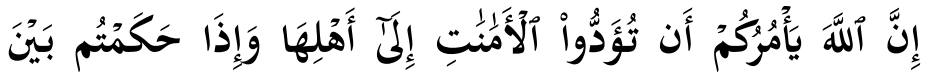

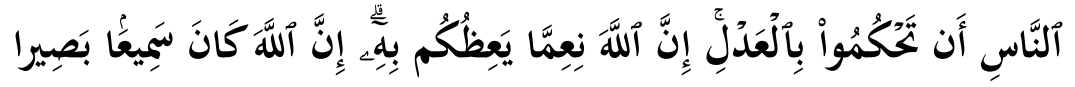

Terjemahnya:

"Sesungguhnya Allah menyuruh kamu menyampaikan amanat kepada yang berhak menerimanya, dan (menyuruh

${ }^{20}$ Departemen Agama RI, Al-Qur'an dan Terjemahannya, Hlm. 150. 
kamu) apabila menetapkan hukum di antara manusia supaya kamu menetapkan dengan adil. Sesungguhnya Allah memberi pengajaran yang sebaik-baiknya kepadamu. Sesungguhnya Allah adalah Maha mendengar lagi Maha melihat."21

e) Musyawarah

Prinsip musyawarah dalam demokrasi sangat penting, karena dalam suatu urusan sebaiknya dimusyawarahkan terlebih dahulu. Apalagi dalam urusan kemasyarakatan seorang dalam menghadapi masalah, seorang pemimpin tidak boleh menetapkan sesuatu tampa ada musyawarah terlebih dahulu. Dalam Islam terdapat suatu surah yang bernama al-Syura hal itu menandakan bahwa musyawarah merupakan suatu prinsip konstitusional. ${ }^{22}$ Sebagaimana dalam QS. AlSyura: 38 .

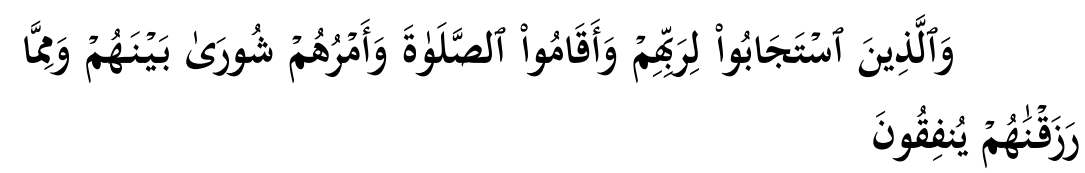

Terjemahnya:

"Dan (bagi) orang-orang yang menerima (mematuhi) seruan Tuhannya dan mendirikan shalat, sedang urusan mereka (diputuskan) dengan musyawarat antara mereka; dan mereka menafkahkan sebagian dari rezki yang Kami berikan kepada mereka." 23

Jadi, sistem demokrasi sesuai dengan Islam, karena dengan adanya prinsip-prinsip yang terdapat dalam demokrasi hal itu menandakan bahwa itu sesuai dengan Islam. hanya saja biasanya yang menyeleweng

${ }^{21}$ Departemen Agama RI, Al-Qur'an dan Terjemahannya, Hlm. 87.

${ }^{22}$ Jawahir Thontowi, Pesan Perdamaian Islam (Cet. I; Yogyakarta: Madyan Press, 2001), Hlm. 63.

${ }^{23}$ Departemen Agama RI, Al-Qur'an dan Terjemahannya, Hlm. 487.

Sangaji Jurnal Pemikiran Syariah dan Hukum 
sistem demokrasi itu adalah para pemegang kekuasaan. Sehingga demokrasi dianggap tidak sesuai dengan Islam.

\section{Sistem Khilafah}

\section{Pengertian Khilafah}

Arti kata khilafah ialah "perwakilan", "penggantian", atau "jawaban khalifah". Istilah ini berasal dari kata Arab, yakni "khalf", yang berarti "wakil", "pengganti", dan "penguasa". ${ }^{24}$ Khilafah adalah istilah yang muncul dalam sejarah pemerintahan Islam sebagai institusi politik Islam. ${ }^{25}$ dalam al-Mu'jam al-Wasit, khilafah diartikan orang yang datang setelah orang lain lalu menggantikan posisinya. ${ }^{26}$

Menurut Ibnu Khaldun (1332-1406), sejarawan dan sosiolog Islam, khilafah adalah tanggungjawab umum yang sesuai dengan tujuan syara' (hukum Islam) dan bertujuan untuk mewujudkan kemaslahatan (kepentingan) dunia dan akhirat bagi umat. Pada hakikatnya, khilafah merupakan pengganti fungsi pembuat syarak, yakni Rasulullah saw sendiri, dalam urusan agama dan urusan politik keduniaan.

Menurut Imam al-Mawardi, ahli Fikih dan politikus Mazhab Syafi'i, mengatakan bahwa dibentuknya khulafah bertujuan untuk mengganti fungsi kenabian guna memelihara agama dan mengatur masalah dunia. Kehadiran institusi kekhalifaan ini dalam sejarah pemerintahan Islam merupakan simbol kesatuan masyarakat muslim. Seseorang yang melaksanakan fungsi khilafah di sebut khalifah. Bentuk jamaknya khulafa atau

${ }^{24}$ Abi Hasim Ahmad ibn Fariibn Zakariya, Mu'jam Maqa>yis al-lughah fi> al-Arabiyah (Bayrut: Da>r al-Fikri, 1998), Hlm. 328.

${ }^{25}$ Abdul Aziz Dahlan, Ensiklopedia Hukum Islam. Hlm. 918.

${ }^{26}$ Ibrahim Mustafa, al-Mu'jam al-Was\}it. Juz I (Cairo: Majma' al-Lugah alA'rabiyah, 1960), Hlm. 251. 
khala'if. Khalifah berarti orang yang menggantikan kedudukan orang sebelumnya; orang yang mengambil alih tempat orang lain sesudahnya dalam berbagai persoalan. ${ }^{27}$

\section{Sejarah Khilafah}

Sejarah timbulnya istilah "khalifah" dan institusi khilafah bermula sejak terpilihnya Abu Bakar as-Siddiq (573634) sebagai pemimpin umat Islam menggantikan Nabi saw sehari setelah Nabi saw wafat. Kemudian berturut-turut terpilih Umar bin al-Khattab (581-644), Usman bin Affan (576-656), dan Ali bin Abi Talib (603-661).

\section{a) Pengangkatan Abu Bakar Sebagai Khalifah}

Setelah tersiar berita bahwa Rasulullah Saw., telah wafat tak lama setelah duduk-duduk dan berbicara dengan mereka, mereka sangat terkejut sekali. 'Umar yang berada di tengah-tengah mereka berdiri dan berpidato, membantah berita itu. Ia mengatakan bahwa Rasulullah Saw., tidak meninggal, melainkan sedang pergi menghadap Tuhan seperti halnya dengan Musa bin Imran, yang menghilang dari masyarakatnya selama empat puluh malam, kemudian kembali lagi setelah tadinya dikatakan meninggal. ${ }^{28}$

Berbeda dengan 'Umar, Abu Bakar sudah yakin bahwa Rasulullah Saw., sudah menghadap sang Ilahi, ia keluar dan berpidato di depan orang banyak, adapun isi pidato Abu Bakar: "Saudara-saudara! Barang siapa mau menyembah Muhammad, Muhammad sudah meninggal. Tetapi barang siapa menyembah Allah swt., Allah Swt., hidup selalu, tak pernah mati.".

Setelah didengarnya Abu Bakar membacakan ayat itu, ‘Umar jatuh tersungkur ketanah. Kedua kakinya

27 Abdul Aziz Dahlan, Ensiklopedia Hukum Islam. Hlm. 919.

${ }^{28}$ Muhammad Husain Haekal, Abu Bakr As-Siddiq, Hlm. 28.

Sangaji Jurnal Pemikiran Syariah dan Hukum 
sudah tak dapat menahan lagi, setelah dia yakin bahwa Rasulullah saw., memang sudah wafat. Orang semua terdiam setelah mendengar dan melihat kenyataan itu. Setelah sadar dari rasa kebingungan, mereka tidak tahu apa yang hendak mereka perbuat. ${ }^{29}$

Jenazah Rasulullah Saw., belum lagi dimakamkan, namun kaum Ansar, yang terdiri dari suku 'Aus dan Khazraj yang merupakan penduduk asli Madinah, berkumpul di Saqifah (aula) Bani Sa'idah untuk memilih pemimpin kaum muslimin. Hal ini di dorong oleh dua faktor, yaitu pertama, kaum Ansar adalah penduduk asli Madinah yang banyak menolong Rasulullah Saw., Sedangkan faktor kedua adalah sense of crisis (kepekaan terhadap krisis) yang dimiliki kaum Ansar dalam menyikapi kefakuman kepemimpinan. Kaum Ansar nampaknya menyadari sepenuhnya bahaya dari sebuah kevakuman yaitu hilangnnya kontrol atau kendali atas pengaruh syiar Islam pada diri kaum muslimin. Namun hal tersebut sampai ke telinga 'Umar. Ia pun kemudian mengajak Abu 'Ubaidah ibn al-Jarrah dan Abu Bakar menuju ke Saqifah. Sementara itu, Ali ibn Abi Talib, al-Zubair ibn al-'Awwam dan Talhah ibn 'Ubaidillah masih berada di kediaman Rasulullah saw., mengurus jenazah beliau saw.

Kaum Ansar tadinya hendak mengusung Sa'ad ibn 'Ubaidah untuk menjadi pemimpin. Namun hal tersebut tertunda dengan kedatangan Abu Bakar, 'Umar dan Abu 'Ubaidah. Hampir saja terjadi konflik antara Muhajirin dan Ansar. Maka Abu Bakar tampil menengahi dan memberi hujjah bahwa kalangan Muhajirinlah yang mesti menjadi pemimpin umat. Setelah kaum Ansar bisa menerima hal tersebut, maka

${ }^{29}$ Muhammad Husain Haekal, Abu Bakr As-Siddiq, Hlm. 29. 
Abu Bakar mengambil inisiatif dengan mengangkat kedua tangan 'Umar dan Abu 'Ubaidah untuk dibaiat sebagai Khalifah. Tetapi 'Umar tidak membiarkan perselisihan itu menjadi perkelahian yang berkepanjangan. Dengan suaranya yang lantang menggelegar ia berkata: "Abu Bakar bentangkan tanganmu." Abu Bakr membentangkan tangan dan oleh 'Umar ia diikrarkan seraya katanya: "Abu Bakar, bukankah Nabi menyuruhmu memimpin Muslimin bersembahyang? Engkaulah penggantinya (khalifahnya). Kami akan mengikrarkan orang yang paling disukai oleh Rasulullah diantara kita semua ini." Menyusul Abu 'Ubaidah memberikan ikrar. "Engkaulah Muhajirin yang paling mulia, menggantikan Rasulullah dalam salat, sesuatu yang paling mulia dan utama dalam agama kita. Siapa lagi yang lebih pantas dari engkau untuk ditampilkan dan memegang pimpinan ini.

Berlanjut hingga keesokan harinya, sampai mayoritas kaum muslimin melakukan baiat kolektif yang menandakan keabsahan pengangkatan beliau. ${ }^{30}$ Setelah Abu Bakar dibaiat seseorang memanggilnya dengan kata-kata, "Ya Khalifatullah." Abu Bakar tidak membiarkan orang itu meneruskan bicaranya, melainkan langsung diputus: "Aku bukan Khalifah Allah, tapi Khalifah Rasulullah."31 Namun begitu, sesungguhnya Abu Bakar sama sekali tidak menginginkan kedudukan itu, karena ia sangat

${ }^{30}$ Ibnu Kasir, al-Bidayah wa al-Nihayah, Jilid VI (Cet. I; Beirut: Dar alKutub al-'Ilmiyyah, 2001), Hlm. 298.

${ }^{31}$ Muhammad Husain Haekal, Abu Bakr As-Siddiq, Hlm. 343.

Sangaji Jurnal Pemikiran Syariah dan Hukum 
menyadari tanggung jawab kepemimpinan di hadapan Allah Swt. ${ }^{32}$

Masa kekhalifahan Abu Bakar merupakan masa kritis perjalanan syiar Islam karena dihadapkan sejumlah masalah seperti kemurtadan dan ketidaksetiaan. Beberapa anggota suku muslim menolak untuk membayar zakat untuk Bait al-Mal (perbendaharaan publik). Kemudian masalah berikutnya adalah munculnya beberapa kafir yang menyatakan dirinya sebagai Nabi, serta sejumlah pemberontakanpemberontakan kecil yang merupakan bibit-bibit perpecahan. ${ }^{33}$

1) Pengiriman Pasukan Usamah ibn Zaid

Semasa hidup, Rasulullah Saw., pernah mengirimkan satu ekspedisi ke Syiria di bawah pimpinan Usamah ibn Zaid. Pengiriman ekspedisi ini sempat diusulkan para sahabat untuk ditarik kembali ke Madinah guna membantu mengatasi masalah dalam negeri. Namun usulan ini di tolak oleh Abu Bakar karena pengiriman ekspedisi ini merupakan amanah dari Rasulullah Saw., Sikap tegas yang ditunjukkan oleh Abu Bakar kelak membuahkan hikmah tersendiri bagi usaha penyelesaian konflik sosial dalam negeri.

Selama 40 hari berperang melawan orang-orang Romawi di Syiria, akhirnya ekspedisi Usamah meraih kemenangan. Keberhasilan ini menimbulkan opini positif bahwa Islam tetap jaya. Akhirnya satu persatu suku-suku yang semula meninggalkan Islam kembali

32 Akram Diya' al-Umri, Asr al-Khilafah al-Rashidah (Madinah; Maktabah al-Abikan, t.tHlm.), Hlm. 51.

${ }_{33}$ Muhammad Yusuf al-Kandahlawi, Mukhtas\{ar Hayah al-Sahabah, terj. Kathur Suhardi, Sirah Sahabat (Cet. I; Jakarta: Pustaka Al-Kautsar, 1998), Hlm. 153. 
memeluk Islam dan loyal terhadap kekhalifahan Abu Bakar.

2) Memberantas Pembangkang Zakat

Pada masa khalifah Abu Bakar banyak orang Islam yang enggan membayar zakat. Keengganan membayar zakat itu baik karena kikir dan kelihaian mereka seperti kelihaiannya dalam mencari dan menyimpan uang, dan pergi kian kemari sampai mengorbankan hidupnya demi memperolehnya, atau karena anggapan bahwa pembayaran itu sebagai upeti yang sudah tak berlaku lagi sesudah Rasulullah tiada. $^{34}$

3) Perlawanan Terhadap Nabi-nabi Palsu

Persoalan dalam negeri yang terakhir dan perlu segera dipadamkan adalah pemberontakan yang digerakkan oleh nabi-nabi palsu seperti al-Aswad al'Ansi dari Yaman, Tulaiha dari Bani Asad di Arab Utara, Sajah binti al-Harits di Suwaid, dan Musailamah al-Kazzab anggota suku Arab Tengah. Namun pemberontakan-pemberontakan tersebut dapat ditumpas oleh pasukan Islam dibawah komando Khalid ibn al-Walid. ${ }^{35}$

4) Perang Riddah

Kabilah-kabilah Abs, Zubyan, Banu Bakr dan semua yang bersekutu dengan mereka, oleh Abu Bakar dihancurkan dan dikeluarkan dari Abraq. ${ }^{36}$ Mereka adalah para kabilah yang murtad dari Islam yang mana semula memeluk Islam, namun setelah Rasulullah saw., wafat, mereka mengangap bahwa

${ }^{34}$ Muhammad Husain Haekal, Abu Bakr As-Siddiq, Hlm. 88.

35 Usman ibn Muhammad al-Khamis, Hiqbah min al-Tarikh (Cet. I; Kairo: Maktabah al-Imam al-Bukhari, 2006), Hlm. 71-74.

${ }^{36}$ Muhammad Husain Haekal, Abu Bakr As-Siddiq, Hlm. 88.

Sangaji Jurnal Pemikiran Syariah dan Hukum 
terputuslah dari ajaran-ajaran yang dibawa oleh Rasulullah Saw., sehingga kembali kepada agama nenek moyang yang mereka anut sebelumnya. Olehnya itu, Abu Bakar melancarkan perang yang sangat menentukan dalam sejarah Islam. Jika perang itu tidak dimenangkan oleh Muslimin, pasti akan menjadi ancaman kembalinya orang-orang Arab ke dalam kehidupan jahiliyah yang pertama. ${ }^{37}$

5) Perang Yamamah

Setelah itu pasukan melanjutkan perjalanan ke Bani Hanifah di Yamamah. Yang diutus oleh Abu Bakar adalah Ikrimah bin Abu Jahal yang bertugas memerangi Musailamah al-Kadzab yang mengaku sebagai Nabi dari Bani Hanifah yang terletak di pesisir pantai timur Arab. ${ }^{38}$

Terjadi sebuah pertempuran sangat sengit yang akhirnya dimenangkan oleh kaum muslimin dan Musailamah terbunuh. Akhirnya, penduduk di tempat itu bertobat dan kembali ke dalam pengakuan Islam. Pada perang ini sejumlah sahabat mati syahid. Diantaranya adalah para penghafal Al Quran. ${ }^{39}$

6) Penaklukan Islam

Setelah permasalahan besar dalam negeri dapat diatasi dengan baik, Abu Bakar memfokuskan pada kebijakan luar negeri, yakni menyelamatkan sukusuku Arab dari penganiayaan pemerintahan Persia dan Romawi. Untuk misi ini, Abu Bakar kembali mengirimkan Khalid ibn al-Walid dengan

${ }^{37}$ Muhammad Husain Haekal, Abu Bakr As-Siddiq, Hlm. 106-107.

38 Istianah Abu Bakar, Sejarah Peradaban Islam, (Malang: UIN-Malang Press, 2008), Hlm.35.

${ }^{39}$ Al-Usairy, Ahmad, Sejarah Islam (Sejak Zaman Nabi Adam Hingga Abad XX), Jakarta: Akbar Media Eka Sarana, 2003), Hlm. 147. 
pasukannya yang akhirnya bisa menguasai Persia, Irak Selatan, Syiria dan Romawi hanya dalam kurun waktu satu tahun.

7) Pengumpulan Al Quran

Berbicara tentang pengumpulan Al Quran kita perlu menengok kembali kebelakang, kepada peristiwa Yamamah. Akibat peristiwa itulah maka mulai timbul gagasan untuk mengumpulkan Al Quran, yang kemudian dilaksanakan. Pelaksanaan ini memakan waktu sampai berakhirnya masa kekhalifahan Abu Bakar sesudah perang Yamamah. ${ }^{40}$ Memang inilah soal-soal yang paling berbahaya dalam sejarah Islam dan kaum Muslimin. Tidak sedikit sahabat Nabi yang sudah hafal Al Quran mati syahid dalam ekspedisi itu. ${ }^{41}$ Olehnya itu, Umar mengusulkan Abu Bakar untuk segera mengumpulkan Al Quran, lalu Abu Bakar memerintahkan Zaid bin Sabit untuk menghimpun Al Quran dari pelepah kurma, kulit binatang, dan dari hafalan kaum muslimin yang masih hidup pada masa itu. Ini adalah satu kerja besar yang dilakukan pada masa pemerintahan Khalifah Abu Bakar.

\section{b) Kekhalifaan Umar bin Khattab (13-23 H / 634-644 M)}

Sebelum Abu Bakar meninggal, ditunjuklah Umar bin Khattab sebagai penggantinya. Menurutnya hanya Umar bin Khattablah yang mampu untuk meneruskan tugas kepemimpinan umat Islam yang waktu itu berada pada saat-saat yang paling menentukan dalam sejarahnya yang akan mempengaruhi keberadaan Islam dan umatnya yang masih muda usianya, khususnya

${ }^{40}$ Muhammad Husain Haekal, Abu Bakr As-Siddiq, Hlm. 316.

${ }^{41}$ Muhammad Husain Haekal, Abu Bakr As-Siddiq, Hlm. 317.

Sangaji Jurnal Pemikiran Syariah dan Hukum 
dengan banyaknya penaklukan-penaklukan umat Islam. ${ }^{42}$

Sebelum Abu Bakar memutuskan untuk menetapkan Umar bin Khattab sebagai penggantinya, terlebih dahulu beliau berkonsultasi dengan tokohtokoh masyarakat yang datang menjenguknya, antara lain : Abd al-Rahman bin Auf, Usman bin Affan, Usaid bin Hudlair al-Anshary, Said bin Zaid dan lain-lain dari kaum Muhajirin dan Anshar. Ternyata mereka tidak keberatan atas maksud Khalifah untuk mencalonkan Umar bin Khattab sebagai penggantinya. ${ }^{43}$

Melihat kondisi umat Islam waktu itu, penunjukan Abu Bakar terhadap Umar sebagai penggantinya merupakan pilihan yang sangat tepat. Umar adalah seorang yang berkharisma tinggi, dan mempunyai sifat yang adil amat disegani terutama terhadap orang yang mengenalnya. Salah satu bukti atas besarnya kharisma dan keadilan Umar dihadapan pengikutnya adalah kebijaksanaannya ketika memecat Khalid bin Walid yang digelari Rasulullah Saw. dengan gelar pedang Allah yang amat dikagumi kawan maupun lawan. Pemecatan itu sendiri dilakukan sewaktu umat Islam sangat membutuhkan seorang panglima perang sehebat Khalid bin Walid. Tunduknya Khalid kepada kebijakan Umar itu menunjukkan betapa hebatnya kharisma Umar bin Khattab di mata kaum muslimin. ${ }^{44}$

42 Yunus Ali al-Muhdhar, Kehidupan Nabi Muhammad SAW dan Amirul Mu'minin Ali bin Abi Thalib, (Semarang: Asy-Syifa, 1992), Hlm. 554

43 Tim Penyusun Textbook Sejarah dan Kebudayaan Islam Direktorat Jenderal Pembinaan Kelembagaan Agama Islam Departemen Agama RI, Sejarah dan Kebudayaan Islam Jilid I (Ujungpandang:IAIN Alauddin, 1982), Hlm. 53

${ }^{44}$ Kisah pemecatan Khalid bin Walid lebih jelasnya dapat dilihat pada tulisan Abbad Mahmud Aqqad dalam kitabnya Abqariayh Umar . 
Umar yang namanya dalam tradisi Islam adalah yang terbesar pada masa awal Islam setelah Muhammad Saw. telah menjadi idola para penulis Islam karena keshalehan, keadilan dan kesederhanaannya. Mereka juga mengannggapnya sebagai personifikasi semua nilai yang harus dimiliki oleh seorang khalifah. Wataknya yang yang terpuji menjadi teladan bagi para penerusnya. ${ }^{45}$

Para ilmuwan Barat pun mengakui ketokohan Umar bin Khattab dalam panggung sejarah Islam. Michael H. Hart menempatkannya pada urutan ke-51 dari seratus tokoh yang dianggap sangat berpengaruh di dunia. ${ }^{46}$

Meskipun pengangkatan Umar bin Khattab sebagai khalifah merupakan fenomena yang baru, yang menyerupai penobatan putra mahkota, tetapi harus dicatat bahwa proses peralihan kepemimpinan tersebut tetap dalam bentuk musyawarah yang tidak memakai sistem otoriter. Sebab Abu Bakar tetap meminta pendapat dan persetujuan dari kalangan sahabat Muhajirin dan Anshar.

Setelah Abu Bakar menyelesaikan tugas kekhalifaannya dan menyusul kepergian Rasulullah saw., Kehadirat Allah Swt. Umar meneruskan langkahlangkahnya untuk membangun kedaulatan Islam sampai berdiri tegak. Kemampuannya dalam melaksanakan pembangunan ditandai dengan keberhasilannya diberbagai bidang.

${ }^{45}$ Philip K. Hitti, History of The Arab, terj. R.CecepLukman Yasin dan Dedi Slamet Riyadi, edisi revisi (Cet.I ; Jakarta: Serambi Limu Semsta, 2008), Hlm. 218-219.

${ }^{46}$ Michael HLM. Hurt, The 100, A Ranking of The Most Influencial Persons in History, terj. Mahbub Junaidi dengan judul Seratus Tokoh yang Paling Berpengaruh dalam Sejarah, (Cet. V; Jakarta: Pustaka Jaya, 1983), Hlm. 264

Sangaji Jurnal Pemikiran Syariah dan Hukum 
Pemerintahan dibawah kepemimpinan Umar dilandasi prinsip-prinsip musyawarah. Untuk melaksanakan prinsip musyawarah itu dalam pemerintahannya, Umar senantiasa mengumpulkan para sahabat yang terpandang dan utama dalam memutuskan sesuatu bagi kepentingan masyarakat. Karena pemikiran dan pendapat mereka sangat menentukan bagi perkembangan kehidupan kenegaraan dan pemerintahan. Umar menempatkan mereka dalam kedudukan yang lebih tinggi dari semua pejabat negara lainnya. Hal ini tidak lain karena dilandasi rasa tanggung jawab kepada Allah Swt. ${ }^{47}$

Di zaman Umar gelombang ekspansi secara besarbesaran pertama terjadi, ibukota Syiria, Damaskus ditaklukkan, dan setahun kemudian (636 M), setelah tentara Bizantium kalah di pertempuran Yarmuk, seluruh daerah Syiriah jatuh ke bawah kekuasaan Islam. Dengan memakai Syiria sebagai basis, ekspansi diteruskan ke Mesir di bawah pimpinan Amr bin Ash dan ke Irak di bawah pimpinan Sa'ad bin Abi Waqash. Iskandaria ditaklukkan pada tahun $641 \mathrm{M}$. Dengan demikian, Mesir jatuh di bawah kekuasaan Islam. AlQadisiyah, sebuah ibukota dekat Hirah di Irak, ditaklukkan pada tahun $637 \mathrm{M}$, dari sana serangan dilanjutkan ke ibukota Persia, al-Madain ditaklukkan pada tahun itu juga. Pada tahun $641 \mathrm{M}$, Musol dapat dikuasai. Pada masa kepemimpinan Umar bin Khattab Ra., wilayah kekuasaan Islam sudah meliputi jazirah

47 Abbas Mahmud Aqqad, Abqariyah Umar, terj. Abdulkadir Mahdamy, Menyusuri Jejak Manusia Pilihan,Umar bin Khattab, (Cet I; Solo:Tiga Serangkai Pustaka Mandiri, 2003), Hlm. 101 
Arabiah, Palestina, Syiriah, sebagian besar wilayah Persia dan Mesir. ${ }^{48}$

Umar mengajak dunia memeluk Islam dengan ajakan yang baik dan penuh hikmah. Setelah pasukan muslim menaklukkan Persia, Umar berwasiat kepada Sa'ad ibn Abi Waqash, "kuperintahkan engkau untuk mengajak mereka memeluk Islam; ajaklah mereka dengan cara yang baik, sebelum memulai pertempuran. Umar juga berwasiat kepada para pemimpin pasukan agar tidak memaksa penduduk setempat untuk mengganti agama mereka dengan Islam. Umar justru berwasiat agar umat Islam dapat memuliakan mereka dan tidak mengganggu praktik-praktik ibadah mereka. ${ }^{49}$

Seiring dengan berkembang dan meluasnya wilayah kekuasaan Islam pada masa Khalifah Umar bin Khattab mengharuskan ia mengatur adminstrasi pemerintahannya dengan cermat. Dalam sejarah umat Islam, Umar bin Khattab dipandang sebagai Khalifah yang cukup berhasil mengembangkan dan mewujudkan tata pemerintahan dan sistem adminstrasi kenegaraan yang baik. Baik dalam kehidupan sosial kemasyarakatan, politik, hukum maupun ekonomi.

Adapun sistem yang beliau terapkan dalam keihidupan sosial kemasyarakatan ialah menerapakan perlunya menghargai hak-hak individu dalam kehidupan masyarakat. Hal itu tampak pada masyarakat yang ditaklukkannya. Beliau memberikan kelonggaran dalam menjalankan ibadah menurut ajaran agamanya masing-masing.

${ }^{48}$ Harun Nasution, Islam Ditinjau dari Berbagai Aspeknya, Jilid. I, (Cet. V; Jakarta: UI Press, 1985), Hlm. 58

${ }^{49}$ Musthafa Murad, Umar ibn al-Khattab, terj. Ahmad Ginanjar Sya'ban dan Lulu M.Sunman, Kisah Hidup Umar Bin Khattab, Hlm. 140.

Sangaji Jurnal Pemikiran Syariah dan Hukum 
Dalam bidang pemerintahan, kemasyarakatan dan kenegaraan, Umar menyelesaikan tiap permasalahan yang dihadapi tidak cukup dengan pengamatan fisik semata-mata. Semua diselesaikan dengan peelitian yang cermat, teliti dan seksama. Kebijakan ini diberlakukan ke seluruh wilayah yang menjadi tanggung jawab kekhalifaannya. ${ }^{50}$

Wilayah kekuasaan yang sangat luas itu mendorong Umar untuk segera mengatur administrasi negara. Administrasi pemerintahan diatur menjadi delapan wilayah propinsi, yaitu: Mekah, Madinah, Syiriah, Jazirah, Basrah, Kufah, Palestina dan Mesir, dan yang menjadi pusat pemerintahannya adalah Madinah. Sehingga dapat dikatakan bahwa Umar bin Khatab telah menciptakan sistem desentralisasi dalam pemerintahan Islam. ${ }^{51}$

Sejak pemerintahan Umar, telah dilengkapi adminstrasi pemerintahan dengan beberapa jawatan yang diperlukan sesuai dengan perkembangan negara pada waktu itu. Jawatan-jawatan penting itu antara lain adalah; Dewan al-Kharaj (jawatan pajak) yang mengelolah adminstrasi pajak tanah di daerah-daerah yang telah ditaklukkan. Dewan al-Hadts (jawatan kepolisian) yang berfungsi untuk memelihara ketertiban dan menindak pelanggar-pelanggar hukum yang nantinya akan diadili oleh qadhi. Beliau juga telah merintis jawatan pekerjaan umum (Nazarat al-Nafiah), Jawatan ini bertangung jawab atas pembangunan dan pemeliharaan gedung-gedung pemerintah, saluran-

50 Abbas Mahmud Aqqad, Abqariyah Umar, terj. Abdulkadir Mahdamy, Menyusuri Jejak Manusia Pilihan,Umar bin Khattab , Hlm. 123.

51 Sulaiman Muhammad al-Thamawy, Umar bin Khattab. (Cet.II; Cairo,t.p.,1996), Hlm. 234 
saluran irigasi, jalan-jalan, rumah-rumah sakit dan sebagainya. ${ }^{52}$

Pada masa pemerintahan Khalifah Umar juga telah didirikan pengadilan, untuk memisahkan antara kekuasaan eksekutif dan yudikatif yang pada pemerintahan Abu Bakar, khalifah dan para pejabat adminstratif merangkap jabatan sebagai qadhi atau hakim. Awalnya konsep rangkap jabatan trersebut juga diadopsi pemerintahan Umar. Tetapi, seiring dengan perkembangan keukasaan kaum muslimin, dibutuhkan mekanisme administraif yang mendukung terselenggaranya sistem pemerintahan yang baik ${ }^{53}$.

Setidaknya ada 3 faktor penting yang ikut andil mempengaruhi kebijakan-kebijakan Umar dalam bidang hukum yaitu militer, ekonomi dan demografis (multi suku):

1) Faktor Militer

Penaklukan besar-besaran pada masa pemerintahan Umar adalah fakta yang tak dapat difungkiri. Beliau menaklukan Irak, Syiria, Mesir, Armenia dan daerahdaerah yang ada di bawah kekuasaan Romawi dan Persia. ${ }^{54}$ Untuk mewujudkan dan menyiapkan pasukan profesional, Umar menciptakan suatu sistem militer yang tidak pernah dikenal sebelumnya yaitu seluruh personil militer harus terdaptar dalam buku catatan negara dan mendapat tunjangan sesuai dengan pangkatnya. Pembentukan militer secara

52 Tim Penyusun Textbook Sejarah dan Kebudayaan Islam Direktorat Jenderal Pembinaan Kelembagaan Agama Islam Departemen Agama RI, Hlm. 77

${ }^{53}$ Musthafa Murad, Umar ibn al-Khattab, terj. Ahmad Ginanjar Sya'ban dan Lulu M.Sunman, Kisah Hidup Umar Bin Khattab, Hlm. 145.

${ }_{54}$ Amiur Nuruddin, Ijtihad Umar bin al-Khattab, (Jakarta, Rajawali, 1991) Hlm. 127

Sangaji Jurnal Pemikiran Syariah dan Hukum 
resmi menuntut untuk melakukan mekanimisme baru yang sesuai dengan aturan-aturan militer.

2) Faktor Ekonomi

Dengan semakin luasnya daerah kekuasaan Islam, tentu membawa dampak pada pendapatan negara. Sumber-sumber ekonomi mengalir ke dalam kas negara, mulai dari kharaj (pajak tanah), jizyah (pajak perlindungan), ghanimah (harta rampasan perang), Fai' (harta peninggalan jahiliyah), tak ketinggalan pula zakat dan harta warisan yang tak terbagi ${ }^{55}$. Penerimaan negara yang semakin bertumpuk, mendorong Umar untuk merevisi kebijakan khalifah sebelumnya (Abu Bakar). Umar menetapkan tunjangan yang berbeda dan bertingkat kepada para rakyat sesuai dengan kedudukan sosial dan kontribusinya terhadap Islam. Padahal sebelumnya, tunjangan diberikan dalam porsi yang sama.

3) Faktor Demografis

Faktor ini juga sangat berpengaruh pada kebijakankebijakan yang diambil oleh Umar. Jumlah warga Islam non-Arab semakin besar setelah terjadi penaklukan sehingga kelompok sosial dalam komunitas Islam semakin beragam dan kompleks sehingga terjadi asimilasi antara kelompok. Terlebih lagi setelah kota Kufah dijadikan sebagai kota pertemuan antarsuku baik dari utara maupun selatan. Perbauran inilah yang membawa pada perkenalan institusi baru.

Usman bin Affan dipilih oleh Dewan Syu>ra> atau formatur yang dibentuk Umar bin al-Khattab yang beranggotakan enam sahabat utama, yaitu Ali bin

55 Amir Syarufuddin, Meretas Kebekuan Ijtihad, (Ciputat, Ciputat Press, 2005) Hlm. 145-156 
Abi Talib, Usman bin Affan, Abdurrahman bin Auf, Sa'd bin Abi Waqqas, Zubair bin Awwam, dan Talhah bin Ubaidillah, yang bertugas memilih salah seorang di antara mereka. ${ }^{56}$ Tim ini dibentuk oleh Umar bin khattab setelah ia, ketika sakit, didesak oleh para sahabat agar menunjuk penggantinya. Bahkan ada yang menyarankan agar ia menunjuk putranya, Abdullah bin Umar bin Khattab (ibnu Umar), karena dianggap cakap dan bijak. Ketika itu Umar bin Khattab berkata, "Demi Allah, aku suka dengan cara ini. Aku tidak menghendaki keluargaku ikut dalam urusan ini sekalipun yang diusulkan itu baik. Cukuplah seorang dari keluarga Umar mendapat kehormatan menjadi khalifah." Ia juga mengatakan, "igatlah, jika aku seseorang menjadi pengganti, sungguh cara demikian telah dilakukan oleh orang yang lebih baik dari pada aku (maksudnya: Abu Bakar as-Siddiq). Tetapi jika aku meninggalkan cara demikian (tidak menunjuk seseorang), maka cara demikianpun telah dicontohkan oleh orang yang lebih utama daripada aku (masudnya: Rasullah Saw.)," akhirnya, dewan Syura $>$ memilih Usman bin Affan sebagai khalifah ketiga. ${ }^{57}$

Setelah Usman bin affan terbunuh pada tahun 656, Ali bin Abi Talib dipilih oleh kaum pemberontak dari Mesir (al-Gafiki) setelah mengajak penduduk Madinah untuk memilih pengganti Usman bin Affan menurut usul mereka, yakni Ali bin Abi Talib.

${ }^{56}$ Samsul Munir Amin, Sejarah Peradaban Islam (Jakarta: Amzah, 2013), Hlm. 104.

${ }^{57}$ Abdul Aziz Dahlan, Ensiklopedia Hukum Islam. Hlm. 919.

Sangaji Jurnal Pemikiran Syariah dan Hukum 
Gelar khalifah pertama kali digunakan oleh Abu Bakar as-Siddiq. Ketika ada sahabat yang menyebutnya khalifatullah (khalifah Allah Swt.), ia menolaknya. Ia mengatakan, "saya bukan khalifatullah, tetapi khalifah Rasulullah saw." Kemudian Umar bin Khattab digelari khalyafatu khalifah Rasulillah (khalifah dari khalifah Rasulullah Saw.), namun ia tidak menyikai gelar ini. Ia menyebut dirinya Amirulmu'minin (pemimpin orang-orang beriman). Usman bin Affan dan Ali bin Abi Thalib juga digelari khalifah Rasulullah Saw. dengan gelar ini maka wewenang dan kekuasaan yang diatributkan kepada mereka adalah sebagai pengganti Muhammad saw dalam kedudukannya sebagai kepala negara yang menjalangkan tugas memimpin umat baik muslim maupun nonmuslim dan memelihara kemaslahatan mereka bukan hanya dalam kedudukannya sebagai pembawa risalah. Artinya, mereka menjadi khulafa' Rasulullah Saw. dalam aspek imamah di samping sebagai pengatur, penyebar agama atau pemimpin spiritual, bukan dalam arti risalah. Karena dengan wafatnya Nabi Muhammad Saw., maka wahyu pun secara otomatis berhenti dan kedudukannya tidak dapat digantikan oleh siapa pun. Dengan demikian mereka adalah kepala negara dan sekaligus pemimpin agama. ${ }^{58}$

Keempat khalifah tersebut dinamakan al-khulafa' arRasyidin, yaitu khalifah-khalifah terpercaya atau yang mendapat petunjuk. Ada yang meyebutnya sebagai khalifah yang amat taat dan setia pada agama, khalifah besar, dan khalifah ortodoks (yang berpegang kuat pada ajaran dan keyakinan). Gelar al-

${ }^{58}$ Abdul Aziz Dahlan, Ensiklopedia Hukum Islam. Hlm. 919. 
khulafa' ar-Rasyidin berkaitan dengan kepemimpinan dan kapasitas mereka sebagai kepala negara serta pemimpin agama yang mempertahankan kemurnian ajaran Islam dalam berbagai aspek kehidupan, sebagaimana telah dicontohkan oleh Rasulullah Saw., dan dalam mewujudkan kemaslahatan umat. ${ }^{59}$

Setelah Nabi Saw. wafat, mereka adalah contoh ideal dalam menghayati dan mengamalkan agama, melaksanakan prinsip pemerintahan Islam, dan dalam membimbing umat. Menurut Ibnu Khaldun, pemerintahan al-khulafa' ar-Rasyidin adalah kekhilafaan sejati. Karena itu, mereka mempunyai derajat yang spesifik dalam pandangan umat Islam.

Pengangkatan Abu Bakar al Siddiq, Umar bin Khattab, Usman bin Affan, dan Ali bin Abi Talib sebagai khalifah-khalifah Rasulullah Saw. menjadi dasar terbentuknya modal pemerintahan Khilafah dalam sejarah Islam, yakni:

- Dinasti Umayyah di Damaskus (41-133 H/661-750 M): 14 khalifah;

- Dinasti Abbasiyah di Baghdad (132-565 H/7501258): 37 khalifah;

- Dinasti Umayyah di Spanyol (139-423 H/7561031): 18 khalifah;

- Dinasti Fatimiyah di Mesir (297-567 H/909-1171 M): 14 khalifah;

- Dinasti Turki Usmani (Kerajaan Ottoman) di Istambul (1300-1922): 39 khalifah;

- Kerajaan Safawi di Persia (1501-1786): 18 syah (raja);

- Kerajaan Mogul di India (1526-1858): 15 raja;

- Dinasti-dinasti kecil lainnya di Timur dan Barat.

${ }^{59}$ Abdul Aziz Dahlan, Ensiklopedia Hukum Islam. Hlm. 919.

Sangaji Jurnal Pemikiran Syariah dan Hukum 
Kerajaan-kerajaan tersebut memakai gelar khalifah dan syah. Bahkan Dunasti Abbasiyah terkadang memakai gelar khalifatullah (khalifah Allah) dan Zillullah fi al-Ard (banyangan Allah di Bumi). Penguasa Turki Usmani menganggap dirinya sebagai khalifah tunggal di dunia Islam. Jika al-khulafa' arRasyidin dipilih secara musyawarah, maka dinastidinasti tersebut menerapkan tradisi pengangkatan raja secara turun-menurun. ${ }^{60}$

Model pemerintahan khilafah di dunia Islam berakhir di Turki sejak Mustafa Kemal Ataturk (1881-1938) menghapuskannya pada tanggal 3 Maret 1924. Umat Islam pernah berusaha untuk menghidupkan kembali khilafah melalui Muktamar khilafah di Cairo (1926) dan kongres Khilafah di Mekah (1928). Di India timbul pula Gerakan Khilafah. Organisasi-organisasi Islam di Indonesia jiga membentuk Komite Khilafah (1926) yang berpusat di Surabaya untuk tujuan yang sama.

Ulama berbeda pendapat tentang dasar pembentukan khilafah. Ada yang mewajibkan karena pertimbangan akal. Para ahli fikih Suni, antara lain Abu Hasan Ali bin Isma'il al-Asy'ari $(260$ H/873 M324 H/935 M), berpemdapat bahwa khilafah itu wajib karena wakyu dan ijmak para sahabat Nabi Saw., untuk membentuk pemerintahan segera setelah wafatnya Nabi Saw. Al-Bagdawi (ahli usul fikih dan sejarawan) mendukung pendapat ini. Al-Baqillani (murid al-Asy'ari, tokoh fikih dan ilmu kalam bermazhab Syafi'i) hanya mengatakan wajib. Menurut Imam al-Mawardi, wajib secara ijmak, dan arti fardu kifayah (kewajiban kolektif atau tanggung

${ }^{60}$ Abdul Aziz Dahlan, Ensiklopedia Hukum Islam. Hlm. 920. 
jawab seluruh umat Islam). Abu al-Ma'ali al-Jawaini hanya mengatakan Ijmak (kosensus), bukan atas dasar nas\} (bukti tekstual) atau perintah wahyu.

Imam al-Gazali, tokoh fikih Mazhab Syafi'i, berpendapat bahwa mendirikan khilafah adalah wajib syar'i (berdasarkan syarak), yang didasarkan pada ijmak dan kategori wajibnya adalah fardu kifayah. Pandangan ini juga dianut oleh Ibnu Khaldun. Sementara itu, menurut Ibnu Taimiyah, tokoh fikih Mazhab Hambali, pemerintahan dibentuk karena ajaran agama untuk melakukan syariat Islam dan mewujudkan kesejahteraan umat. Adapun menurut aliran Muktazilah, wajib karena pertimbangan akal.

Aliran-aliran politik dalam Islam juga tidak sepakat tentang siapa yang berhak menjadi khalifah. Menurut Syiah, khalifah harus berasal dari kerabat Nabi Saw, menurut Sunni, dari keturunan Kuraisy; dan menurut aliran Khawarij dan Muktazilah, siapa saja boleh menjadi khalifah. ${ }^{6}$

\section{Kesimpulan}

1. Demokrasi adalah suatu aturan kelembagaan dalam rangka mengambil suatu keputusan politik di mana masing-masing orang memiliki kekuatan untuk memutuskan dan berjuang secara kompratif untuk memperoleh dukungan atau suara rakyat. Adapun prinsip-prinsip demokrasi dalam Islam adalah persaudaraan, persamaan, kebebasan, keadilandan musyawarah

2. khilafah adalah lembaga pemerintahan dalam Islam yang bertujuan untuk mewujudkan kemaslahatan (kepentingan) dunia dan akhirat bagi umat. Dalam hal khilafah, ada dua masalah pokok, yaitu; pertama, prosedur pengangkatan

${ }^{61}$ Abdul Aziz Dahlan, Ensiklopedia Hukum Islam. Hlm. 920.

Sangaji Jurnal Pemikiran Syariah dan Hukum 
mereka sebagai pengganti Nabi saw dalam memimpin umat Islam, sementara baik Al Quran maupun Nabi saw sendiri tidak memberi penjelasan rinci terhadap al ini dan kedua, wewenang dan kekuasaan yang diatributkan kepada para pengganti Nabi Saw. tersebut. 


\section{Daftar Pustaka}

Al Quran al-Karim

Amin, Samsul Munir. Sejarah Peradaban Islam. Jakarta: Amzah, 2013.

Abdillah, Masykuri. Respons of Indonesia Muslim Intelectuals to the Concept of Democracy. Cet. I; Yogyakarta: Taitara Wacana, 1999.

al-Muhdhar, Yunus Ali. Kehidupan Nabi Muhammad SAW dan Amirul Mu'minin Ali bin Abi Thalib. Semarang: Asy-Syifa, 1992.

Dahlan, Abdul Aziz. Ensiklopedia Hukum Islam. Cet. I; Jakarta: Ichtiar Baru Van Hoeve, 1996.

Departemen Agama RI, Al Quran dan Terjemahannya. Jakarta: Da>r As-Sunnah, 2002.

Djazuli, Fikh Siyasah: Implemetasi kemaslahatan Umat dalam RambuRambu Syariah. Cet. III; Jakarta: Prenada Media Group, 2003.

Fachruddin, Fuad. Agama dan Pendidikan Demikrasi, Pengalaman Muhammadiyah dan Nahdlatul Ulama. Cet. I; Jakarta: Pustaka Alvabet, 2006.

Haekal, Muhammad Husain, Abu Bakr As-S\{iddiq. Cet. IX; Jakarta: Litera Antar Nusa, 2009.

Jurdi, Syarifuddin, Pemikiran Polotik Islam Indonesia: Pertautan Negara, Khilafah, Masyarakat Madani dan Demokrasi. Yogyakarta: Pustaka Belajar, 2008.

Mahmud MD, Muhammad. Demokrasi dan Konstitusi di Indonesia. Cet. II; Jakarta: PT Rineka Cipta, 2003.

Mustafa, Ibrahim. al-Mu'jam al-Was\}it. Juz I. Cairo: Majma' alLugah al-A'rabiyah, 1960.

R. Wiranto, Djamaluddin Dt, Singomangkuto dan Djamadi, Ahliahli Pikir Besar Tentang Negara dan Hukum. Jakarta: PT Pembangunan, 1980.

Sjadzali, Munawir, Islam dan Tata Negara; Ajaran Sejarah dan Pemikiran. Cet. V; Jakarta: UI Press, 1993.

Sangaji Jurnal Pemikiran Syariah dan Hukum 
Tamara, Nasir. dan Elza Peldi Taher, Agama dan Dialog Antar Peradaban. Cet. 1; Jakarta: Paramadina, 1996.

Thontowi, Jawahir. Pesan Perdamaian Islam. Cet. I; Yogyakarta: Madyan Press, 2001.

Zakariya, Abi Hasim Ahmad ibn Faris ibn. Mu'jam Maqa>yis allughah fi al-Arabiyah. Bayrut: Da>r al-Fikri, 1998. 